\title{
Assessment of functional integrity of liver among workers exposed to soluble nickel compounds during nickel plating
}

\begin{abstract}
The present study investigates the functional integrity of liver among workers exposed to nickel during nickelplating process. The functional integrity of liver was assessed in 69 workers who are exposed to nickel during nickel plating and considered as nickel-exposed workers; and 50 administrative workers residing in same city, but away from the place of work of study group, were considered as control group. The level of urine nickel was measured by using a flameless atomic absorption spectrophotometer. Using kits supplied by Bayer Diagnostics, we determined serum markers of liver function tests. Results: The levels of urine nickel were significantly increased in high-and moderate-exposure groups as compared to control group. The levels of serum transaminases -viz, alanine transaminase and aspartate transaminase-were significantly increased in nickelexposed workers, who had high urine nickel levels as compared to control group. The level of serum albumin was negatively correlated with urine nickel levels. The levels of serum transaminases and serum $\gamma$-glutamyltranspeptidase were positively and significantly correlated with urine nickel levels. Conclusion: Results indicate that workers who had high urine nickel levels had a consistent effect on hepatic inflammatory function.
\end{abstract}

Key words: Hepatotoxicity, nickel plating, urine nickel

engaged in this process are exposed to nickel through inhalation, ingestion and dermal contact. Inhalation is the primary route of occupational exposure to metals. ${ }^{[2]}$ Previous studies on occupational exposure to nickel during nickel-plating process reported lung damages, allergic skin reaction, renal dysfunction and histopathlogical changes in nasal mucous. ${ }^{[3-7]}$ Nickel causes increased levels of aspartate aminotransferase, alanine aminotransferase and gamma-glutamyl-transpeptidase in liver and serum of animals with the administration of nickel salts. ${ }^{[8-12]}$ Sunderman et $a I^{[13]}$ reported mild transient hyperbilirubinemia in workers with acute exposure to nickel compounds. Currently, no reports are available regarding occupational exposure to nickel and effects on functional integrity of liver. Therefore, the present study was undertaken to investigate the functional integrity of liver among workers exposed to nickel during nickel plating.

\section{MATERIALS AND METHODS}

\section{INTRODUCTION}

Pollution in the environment and human exposure to nickel occurs in natural and human activities. Electroplating process is a source of metal pollution induced by human activity. The process of nickel plating involves three steps: Cleaning, plating and post-treatment of the articles. Nickel (Ni) is used as soluble salts as nickel sulphate and nickel chloride in electroplating different articles used in watch manufacturing processes. The temperature of $50^{\circ} \mathrm{C}$ is maintained in the electroplating bath. At this temperature, nickel salts are decomposed into metal ions. In the biological system, nickel forms a complex with adenosine triphosphate, amino acids, peptides, proteins and deoxyribonucleic acid. ${ }^{[1]}$ The workers
The study involved 119 male workers, who were divided into two subgroups. The first subgroup consisted of 69 workers who were recruited in the nickel-plating industry located in Bangalore, India; this group was considered 'nickel-exposed workers'. These 69 workers were further categorized into two groups according to their urine nickel levels, viz, i) 26 workers were high exposed group and their urine nickel was more than 10 $\mu \mathrm{g} / \mathrm{g}$ of creatinine and ii) 43 workers were moderate exposed group and
Ravi Babu K., Rajmohan H. R., Rajan B. K. Regional Occupational Health Centre (Southern), Indian Council of Medical Research, Bangalore, India

For correspondence: Ravi Babu Kalahasthi, Regional Occupational Health Centre (Southern), Bangalore Medical College Campus, Indian Council of Medical Research, Bangalore - 560002 , India.

E-mail:

kalahasthi20012002@ yahoo.co.in

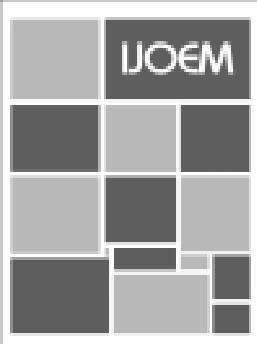


their urine nickel level was $\leq 10 \mu \mathrm{g} / \mathrm{g}$ of creatinine. The nickelexposed workers had an exposure to nickel ranging from 1220 years. The second subgroup comprising of 50 office workers with no exposure to nickel was considered 'control group'. The control group subjects were matched for age and socioeconomic status with nickel-exposed workers. Demographic information, work history and habits of all subjects were obtained through a questionnaire.

Urine samples of the workers were collected in metal-free polyethylene bottles at the end of a shift and used for the estimation of nickel according to Andersen Ivar et al. ${ }^{[14]}$ The digested samples were measured for nickel in a flameless atomic absorption spectrophotometer (GBC-AAS with GF3000). The standardization of nickel was done with the working standard solutions of 0 to $30 \mu \mathrm{g} / \mathrm{l}$. The calibration curve was found to be linear. The internal standard of nickel $3 \mu \mathrm{g} / \mathrm{l}$ was added to urine and analyzed and it was found that the recovery was $98 \%$. The urinary nickel was standardized with urinary creatinine concentration measured by the Jaffe reaction method developed by Husdan and Abraham. ${ }^{[15]}$

Five milliliters of whole blood was collected in test tubes and centrifuged at $3000 \mathrm{rpm}$ for $10 \mathrm{~min}$ at $4^{\circ} \mathrm{C}$. Serum and the red blood cells were separated. The collected serum was used to assess functional integrity of liver. The serum alanine transaminase (ALT) and serum aspartate transaminase (AST) were used to assess the hepatic inflammatory function. Alkaline phosphatase (ALP) and serum $\gamma$-glutamyltranspeptidase (SGGT) were used to assess chlolestasis function. The determination of serum total bilirubin was used to assess hepatic clearance function. The determination of serum total protein and albumin was used to assess synthetic function of liver. The assessment of functional integrity of liver was conducted based on the guidelines published by Rada Jesica et $a l^{[16]}$ Mosley et $a I^{177]}$ and Morgan et $a l^{[18]}$ All the biochemical markers were estimated by using a Random Access Analyser-50 (RA-50) and kits supplied by Bayer Diagnostics. A quality-controlled serum of Bayer Diagnostics was used.

\section{Statistical analysis}

SPSS package version 7.5 for Windows was used for the statistical analysis of data. Student t-test was used to compare the mean levels between nickel-exposed workers and control group. The $\chi^{2}$ test was used to compare the abnormal frequencies of liver function tests between nickel-exposed workers and control group. Pearson's correlation coefficient was used to find out the association between urine nickel levels and liver function indicators.

\section{RESULTS AND DISCUSSION}

The mean age, duration of exposure, body mass index and levels of urine nickel in nickel-exposed workers and control groups are presented in Table 1. The mean age and body mass index of nickel-exposed workers and control group were suitably matched. The level of nickel in urine was considered as a bio-indicator of nickel-exposed workers. ${ }^{[19]}$ The levels of urine nickel were significantly increased in high- and moderate-exposed groups as compared to control group. The results of urinary nickel presented in this study were very close to the results published by Kiilunen et $a I^{[20]}$ and Sunderman et al. ${ }^{[2]}$

Mean levels of liver function tests in high-and moderateexposed workers and control group are presented in Table 2. The mean values of hepatic inflammatory function, such as serum alanine transaminase and aspartate transaminase levels, were significantly increased in high-and moderateexposed workers as compared to control group. The mean levels of synthetic function, such as serum total protein and albumin, were decreased in high-and moderate-exposed

Table 1: Mean age, duration of exposure, body mass index and urine nickel in study subjects

\begin{tabular}{lccc}
\hline Characteristics & \multicolumn{3}{c}{ Exposed group } \\
\cline { 2 - 4 } & Highly & Moderate & Control \\
\hline No. of workers & 26 & 43 & 50 \\
Age (years) & $42.4 \pm 3.39$ & $43.0 \pm 2.79$ & $41.9 \pm 3.48$ \\
Duration of exposure (years) & $16.1 \pm 2.52$ & $15.3 \pm 2.32$ & $15.1 \pm 2.40$ \\
BMl $\left(\mathrm{Kg} / \mathrm{cm}^{2}\right.$ ) & $27.6 \pm 1.98$ & $27.5 \pm 2.00$ & $27.0 \pm 2.22$ \\
Urine nickel & $15.5 \pm 4.84^{* *}$ & $7.07 \pm 1.38^{* *}$ & $3.01 \pm 1.04$ \\
(mg/g of creatinine) & & & \\
\hline${ }^{* *} P<0.001$ & & &
\end{tabular}

Table 2: Mean values of serum liver function indicators in study subjects

\begin{tabular}{lccc}
\hline \multirow{2}{*}{$\begin{array}{l}\text { Liver function } \\
\text { parameters }\end{array}$} & \multicolumn{3}{c}{ Exposed group } \\
\cline { 2 - 4 } & Highly & Moderate & Control \\
\hline Total protein (g/dl) & $7.20 \pm 0.25$ & $7.24 \pm 0.28$ & $7.25 \pm 0.30$ \\
Albumin $(\mathrm{g} / \mathrm{dl})$ & $3.90 \pm 0.12$ & $3.87 \pm 0.14$ & $4.0 \pm 0.18$ \\
Total bilirubin (mg/dl) & $1.14 \pm 0.12$ & $1.10 \pm 0.18$ & $1.08 \pm 0.20$ \\
ALT (IU/L) & $33.0 \pm 6.59^{*}$ & $31.1 \pm 7.6$ & $28.9 \pm 6.38$ \\
AST (IU/L) & $35.5 \pm 7.68^{* *}$ & $33.5 \pm 8.3^{*}$ & $29.5 \pm 7.44$ \\
ALKP (IU/L) & $152.5 \pm 30.0$ & $145.8 \pm 32.6$ & $146.0 \pm 21.0$ \\
SGGT (IU/L) & $29.7 \pm 7.74$ & $28.8 \pm 8.47$ & $29.0 \pm 5.20$ \\
\hline${ }^{*} P<0.05$ and ${ }^{* *} P<0.001$ & & &
\end{tabular}

Table 3: Distribution of abnormal frequencies of liver function tests in study subjects

\begin{tabular}{|c|c|c|c|c|}
\hline \multirow{2}{*}{$\begin{array}{l}\text { Liver function } \\
\text { parameters }\end{array}$} & \multirow[b]{2}{*}{$\begin{array}{r}\text { Normal } \\
\text { ranges }\end{array}$} & \multicolumn{3}{|c|}{ Exposed group } \\
\hline & & $\begin{array}{l}\text { Highly } \\
(\mathrm{n}=26)\end{array}$ & $\begin{array}{c}\text { Moderate } \\
(n=43)\end{array}$ & $\begin{array}{l}\text { Control } \\
(n=50)\end{array}$ \\
\hline Total protein (g/dl) & $<6.9$ & $1(3.84)$ & $2(4.65)$ & $0(0.00)$ \\
\hline Albumin (g/dl) & $<3.7$ & $1(3.84)$ & $1(2.32)$ & $1(2.00)$ \\
\hline Total bilirubin (mg/dl) & $>1.2$ & $2(7.69)$ & $3(6.97)$ & $2(4.00)$ \\
\hline ALT (IU/L) & $>40$ & $6(23.07)^{*}$ & $6(13.95)$ & $3(6.00)$ \\
\hline AST (IU/L) & $>45$ & $6(23.07)^{*}$ & $6(13.95)$ & $3(6.00)$ \\
\hline ALKP (IU/L) & $>170$ & $4(15.38)$ & $4(9.30)$ & $2(4.00)$ \\
\hline SGGT (IU/L) & $>55$ & $1(3.84)$ & $2(4.65)$ & $1(2.00)$ \\
\hline
\end{tabular}


Table 4: Correlation coefficients $(r)$ between liver function indicators and urine nickel

\begin{tabular}{lccccccc}
\hline Variables & $\begin{array}{c}\text { Urine } \\
\text { Nickel }\end{array}$ & $\begin{array}{c}\text { Total } \\
\text { protein }\end{array}$ & Albumin & $\begin{array}{c}\text { Total } \\
\text { Bilirubin }\end{array}$ & ALT & AST & ALKP \\
\hline Urine nickel & 1.000 & - & - & - & - & - & - \\
Total protein (g/dl) & -0.179 & 1.000 & - & - & - & - & - \\
Albumin (g/dl) & $-0.228^{*}$ & $0.305^{* *}$ & 1.000 & - & - & - \\
Total bilirubin & 0.086 & -0.055 & -0.078 & 1.000 & & - \\
ALT (IU/L) & $0.188^{*}$ & -0.099 & -0.069 & 0.164 & 1.000 & 1.000 & \\
AST (IU/L) & $0.249^{* *}$ & -0.099 & -0.114 & 0.154 & $0.913^{* *}$ & $0.230^{*}$ & 1.000 \\
ALKP (IU/L) & 0.027 & 0.070 & -0.003 & -0.128 & $0.292^{*}$ & $0.234^{*}$ & 0.069 \\
SGGT (IU/L) & $0.209^{* *}$ & 0.029 & 0.074 & 0.062 & $0.308^{* *}$ & 1.000 \\
\hline
\end{tabular}

${ }^{*}$ Significant at $P<0.05,{ }^{*}$ Significant at $P<0.01$

workers as compared to control group, but this decrease was not significant. Mean levels of cholestasis function, viz, serum alkaline phosphatase and serum $\gamma$ - glutamyl-trans peptidase, were increased in highly exposed workers as compared to control group but not in significant. The mean levels of hepatic clearance function, such as serum total bilirubin, increased in both the nickel-exposed groups as compared to control group, but not significantly. The mean levels of liver function tests of present study were similar to other studies with similar mean age and body mass index. ${ }^{[22-23]}$

Table 3 presents the distribution of abnormal frequencies of liver function tests in nickel-exposed workers and control group. The distribution of abnormal frequencies of liver function among nickel-exposed workers and control group was done by using $95^{\text {th }}$ percentile values (i.e., Mean +2 standard deviation) for AST, ALT, ALP, SGGT and total bilirubin; and $5^{\text {th }}$ percentile values for serum total protein and serum albumin of control group. It was found that the abnormal frequencies of synthetic, chloestasis and clearance function were not significantly altered in high- and moderateexposure groups as compared to controls. The abnormal frequencies of serum hepatic inflammatory function-viz, alanine transaminase and aspartate transaminase levelswere significantly altered in the high-exposure group.

Table 4 presents the correlation coefficients (r) between urine nickel and liver function indicators among study subjects. A negative correlation was found between serum albumin and urine nickel levels. Positive correlation coefficients were found between the levels of alanine transaminase, aspartate transaminase and serum $\gamma$ - glutamyl-trans peptidase; and urine nickel levels. The associations between urine nickel levels; $s_{i}$ and serum aspertate transaminase, serum $\gamma$-glutamyltrans peptidase levels were found to be significant at $P<0.01$. The associations between urine nickel and serum albumin and alanine transaminase were found to be significant at $P<0.05$.

\section{CONCLUSION}

The serum hepatic inflammatory functions were significantly altered in high nickel exposed workers as compared to moderate exposure and control group. The results of the study indicate that the exposure of soluble nickel compounds had consistent effect on hepatic inflammatory function in nickelexposed workers. The results of present study agree with literature data regarding nickel-induced hepatotoxicity in animal studies.

\section{ACKNOWLEDGMENT}

We are grateful to the Director, National Institute of Occupational Health, Ahmedabad, for his encouragement and support throughout this study. We are thankful to Mrs. A. Mala for her technical help.

\section{REFERENCES}

1. WHO Regional Office for Europe. Nickel In: and Chapter 6.10 of Air Quality Guidelines $2^{\text {nd }}$ ed. 2000. p. 1-14.

2. Kelleher P, Pacheco K, Newman LS. Inorganic dust pneumonias: the metal related parenchyma disorders. Environ Health Perspect 2000;108:685-96.

3. Bright P, Burge PS, O'Hickey SP, Gannon PF, Robertson AS, Boran A. Occupational asthma due to chrome and nickel electroplating. Thorax 1997;52:28-32.

4. Kanerva L, Kilunen M, Jolanki R, Estlander T, Aitio A. Hand dermatitis and allergic patch reactions caused by nickel in electroplaters. Contact Dermatitis 1997;36:137-40

5. Liu CS, Kuo HW, Lai JS, Lin TI. Urinary N-acetyl-B-Dglucosaminidase as an indicator of renal dysfunction in electroplating workers. Int Arch Occup Environ Health 1998;71:348-52.

6. Sunderman FW Jr. Nasal toxicity, carcinogencity and olfactory uptake of metals. Ann Clin Lab Sci 2001;31:3-24.

7. Torjussen W, Solberg LA, Hogetveit AC. Histopathologic changes of nasal mucosa in nickel workers: A pilot study. Cancer 1979;44:963-74.

8. Mathur AK, Singh BN, Singh A, Singh S, Shanker R, Narang S. Hepatotoxicity of nickel, sodium lauryl sulphate and their combination after repeated dermal application in guinea pigs. J Environ Sci Health Part A $1991 ; 26: 1333-43$.

9. Sidhu P, Garg ML, Morgenstern P, Vogt J, Butz T, Dhawan DK. Role of Zinc regulating the levels of hepatic elements fallowing nickel toxicity in rats. Biol Trace Elem Res 2004;102:161-72

10. Donskoy E, Donskoy M, Forouhah F, Gillies CG, Marzouk A, Reid $\mathrm{MC}$, et al. Hepatic toxicity of nickel chloride in rats. Ann Clin Lab Sci 1986;16:108-17.

11. Ahmed S, Rahaman A, Saleem M, Athar M, Sultana S. Ellagic acid ameliorates nickel induced biochemical alterations: Diminution of oxidative stress. Hum Expl Toxicol 1999;18:691-8.

12. Sidhu P, Garg ML, Dhawan DK. Protective role of zinc in nickel 
induced hepatotoxicity in rats. Chem Biol Interact 2004;150:199-209.

13. Sunderman Jr FW, Dingle B, Hopfer SM, Swift T. Acute nickel toxicity in electroplating workers who accidentally ingested a solution of nickel sulfate and nickel chloride. Am J Ind Med 1988;14:257-66.

14. Andersen I, Torjussen W, Zachariasen H. Analysis of nickel in plasma and urine by electro thermal atomic absorption spectrometry, with sample preparation by protein precipitation. Clin Chem 1978;24:1198-202.

15. Husdan H, Rapoport A. Estimation of creatinine in Jaffe reaction. Clin Chem 1969;14:222-38.

16. Rada J. Modern functional diagnostics in liver disease. Arch Gastroentrohepatol 2001;20:1-2.

17. Morgan DJ, Elliott SL, Gabriel H. Quantitative liver function test: A realizable goal. Can J Gastroentrol 1991;5:77-85.

18. Moseley RH. Evaluation of abnormal liver function test. Med Clin N Am 1996;80:887-906.

19. Oliveira JP, de Siqueira ME, da Silva CS. Urinary nickel as bioindicator of workers' Ni exposure in a galvanizing plant in Brazil. Int Arch Occup Environ Health 2000;73:65-8.

20. Kiilunen M, Aitio A, Tossavainen A. Occupational exposure to nickel salts in electrolytic plating. Ann Occup Hyg 1997;41:189-200.

21. Sunderman FW Jr. Biological monitoring of nickel in humans. Scand J Work Environ Health 1993;19:34-8.

22. Fueeuqh S, Anitha D, Venketesh T. Estimation of reference values in liver function tests in health plan individuals of an urban South Indian population. Indian J Clin Biochem 2004;19:72-9.

23. Bathum L, Petersen HC, Rosholm JU, Hyltoft Petersen P, Vaupel J, Christensen K. Evidence for a substantial genetic influence on biochemical liver function tests: Results from a population based Danish twin study. Clin Chem 2001;47:81-7.

Source of Support: Nil, Conflict of Interest: None declared. 